\title{
FUS/CREB3L1 Fusion Gene
}

National Cancer Institute

\section{Source}

National Cancer Institute. FUS/CREB3L1 Fusion Gene. NCI Thesaurus. Code C101055.

A fusion gene that results from a chromosomal rearrangement involving chromosomes

11 and 16 which fuses the first 6 or 9 exons of the FUS gene with exon 5 of the CREB3L1 gene. This rearrangement is associated with fibrosarcoma. 